\title{
UNDERSTANDING PRAGMATICS AND PRAGMATIC COMPETENCE IN ELT MATERIALS
}

\author{
Nurdiana* \\ English Language and Culture Department, Bunda Mulia University \\ Received on 23 September 2019 / Approved on 30 September 2019
}

\begin{abstract}
Pragmatics is a branch of linguistics concerned with utterance and speaker meaning. With regard to English language teaching (ELT) materials, pragmatics may deal with function in English or language functions - that is what or which language expression commonly used in particular situations. Speaking about function, there are some pragmatic aspects which we should be knowledgeable of. The present paper attempts to discuss what the pragmatic aspects are and their significance in the teaching of language functions through ELT materials. To discuss these pragmatic aspects, a library research was deployed by referring to previous studies on pragmatics and pragmatic competence in language teaching, including the author's investigation on pragmatics in ELT materials. The results indicate that it is imperative for English language teachers to understand pragmatics in ELT materials as it helps them to teach language functions which are pragmatically effective or functional.
\end{abstract}

Keywords: language functions, sociopragmatics, pragmalinguistics, meta-pragmatic information, ELT materials

\begin{abstract}
ABSTRAK
Pragmatik adalah salah satu bidang ilmu dalam linguistik. Terkait dengan bahan ajar bahasa Inggris, pragmatik dapat berkenaan dengan fungsi bahasa dalam bahasa Inggris yaitu ekspresi bahasa apa yang dapat digunakan di konteks tertentu. Berbicara tentang fungsi bahasa, ada beberapa aspek pragmatik yang harus diketahui. Oleh karena itu, makalah ini membahas apa saja aspek pragmatik tersebut and signifikansinya dalam pengajaran bahasa melalui bahan ajar. Untuk mengkaji aspek pragmatik ini, makalah dibuat dengan mengaju pada penelitian sebelumnya yang berhubungan pragmatik dan kompetensi pragmatik dalam pengajaran bahasa, termasuk penelitian yang dilakukan oleh penulis berkenaan dengan bahan ajar bahasa Inggris. Hasil dari penelitian berbasis telaah terhadap penelitian sebelumnya ini adalah pengajar bahasa Inggris wajib memahami pragmatik dalam bahan ajar karena pemahaman ini akan membantu mereka dalam mengajarkan fungsi bahasa terkait pragmatik dengan efektif.
\end{abstract}

Kata Kunci: fungsi bahasa, sosiopragmatik, pragmalinguistik, informasi meta-pragmatik, bahan ajar bahasa Inggris

\section{INTRODUCTION}

Being able to communicate appropriately is one of the objectives of learning a language. Therefore, in English language teaching context, language teachers are encouraged to figure out how they can reach the objective. One way to do so is by understanding pragmatics in English language teaching (ELT) materials. Pragmatics is a branch of linguistics dealing with language use, language in context, language appropriateness, and language awareness. It is closely related to cultures and therefore, it is occasionally labelled as cross-cultural pragmatics (Thomas, 1983). According to Yule (1996), pragmatics is the study of what speakers communicate and its interpretation by the hearers. Crystal (2003) defines pragmatics as the study of language use which focuses on users' point of view and how the language used affects communication. Thomas (1999)

*Author(s) Correspondence:

E-mail: nurdiana@bundamulia.ac.id 
pointed out that there are five areas covered in pragmatics: meaning disambiguation, complete meaning transfer, differentiating utterance meaning from what speakers intend to say, how hearers interpret utterances, and figuring out why people communicate.

As pragmatics highlights language use in context, English as a Foreign Language (EFL) learners are imperative to be knowledgeable of pragmatics. The implementation of pragmatics in language teaching and learning might be dealt with pragmatic competence. Pragmatic competence is defined as the ability to convey and interpret meaning and to use language in context appropriately. To acquire the competence, language learners must have knowledge of language (language form) and how to use the language in particular situations or context in appropriate ways. (Saville-Troike, 2006 and Kasper, 1997, as cited in Wichien and Aksornjarung, 2011; Canale, 1983, as cited in Nguyen, 2011).

Studies on pragmatic competence in ELT materials have been conducted for years. For example, Boxer and Pickering (1995) reported that many ELT materials put more emphasis on linguistic competence than on pragmatic competence which serves communicative functions. Another study conducted by Vallenga (2004) shows that the English as a Second Language (ESL) and EFL textbooks she analysed contained inadequate pragmatic competence so that learners are unlikely to acquire the competence. Some other studies reported that textbooks did not include accurate and adequate pragmatic information (Nguyen, 2011; Kohandani, Farzaneh \& Kazemi, 2014) and the conversations in the textbooks analysed are pragmatically ineffective and are not functional (Soozandehfar, 2011).

In this paper, the term pragmatic competence refers to what Thomas (1983) proposed-language users' ability to use language effectively to be able to attain specific purposes and to comprehend how language is used in context. Thomas' pragmatic competence is divided into two main aspects: sociopragmatic and pragmalinguistic competence. When language users are not able to achieve the competence, failure occurs. Thus, sociopragmatic competence is compared to sociopragmatic failure, and pragmalinguistic competence is equalized with pragmalingustic failure. In order to understand the concept of sociopragmatics and pragmalinguistics, both their competence and failure, other pragmatic aspects should be examined such as language functions and meta-pragmatic information. As this paper attempts to figure out how we can understand pragmatics in ELT materials, four pragmatic aspects will be discussed: language functions, meta-pragmatic information, sociopragmatics, and pragmalinguistics.

\section{LITERATURE REVIEW}

\section{Language Functions and Meta-Pragmatic Information}

In ELT materials, Thomas' (1983) pragmatic competence is closely related to language functions. Basically, language functions refer to functional language use. Language functions, according to Richards and Schmidt (2010, p. 233), are defined as "the purpose for which an utterance or unit of language is used". Harmer (2007) underlined that language functions can be realized in different language forms. For example, to invite someone to have dinner in a restaurant, people can use the following language expressions:

$>$ 'Would you like to have dinner in the restaurant?'

$>$ 'How about having dinner in the restaurant?'

$>$ 'I was wondering if you might like to have dinner in the restaurant?'

Blundell, Higgens and Nigel (1982) classified 135 language functions with over 3,000 language expressions. Each function has particular language expressions and they are realized based on the setting, topic, social relationship, and psychological attitude. As a result, speakers of English know when to use

\footnotetext{
*Author(s) Correspondence:

E-mail: nurdiana@bundamulia.ac.id
} 
those expressions appropriately. The following are the examples of appropriate and inappropriate use of language expressions.

"Debby and Jill are friends. In an informal occasion, Debbie said, “I'm sorry, Jill.” Jill replied, "An apology is not quite necessary." In this situation, the way Jill replies to Debby seems to be over-formal and ridiculous. Perhaps, the more appropriate expression is "Oh, don't worry. That's alright."

\section{(Blundell, Higgens \& Nigel, 1982, p. ix)}

Blundell, Higgens and Nigel (1982) further said that if we use language appropriately, it will result in appropriate language use and vice versa. The situations below show us how language use appropriateness and inappropriateness affect the conversations.

Situation: $\mathrm{Mr}$ Smith, (the superior), is chairing a meeting.

\begin{tabular}{|c|c|c|c|}
\hline setting & pub & $\begin{array}{r}\text { bus stop; shop } \\
\sqrt{Z}\end{array}$ & $\begin{array}{l}\text { boardroom; } \\
\text { ceremonial } \\
\text { reception }]\end{array}$ \\
\hline topic & $\begin{array}{l}\text { the latest football } \\
\text { match; a TV } \\
\text { comedy program }\end{array}$ & weather; travel & $\begin{array}{l}\text { an important } \\
\text { business deal }\end{array}$ \\
\hline social relationship & $\begin{array}{l}\text { a friend; child; close } \\
\text { colleague }\end{array}$ & $\begin{array}{l}\text { a stranger in the } \\
\text { street; taxi-driver; } \\
\text { customs officer }\end{array}$ & $\begin{array}{c}\text { a senior colleague } \\
\Omega\end{array}$ \\
\hline psychological attitude & $\begin{array}{l}\text { relaxed; } \\
\text { hearted }\end{array}$ & $\begin{array}{l}\text { no strong feelings } \\
\text { either way }\end{array}$ & very serious \\
\hline probable language & informal language & neutral language & formal language \\
\hline
\end{tabular}

Table 1. Typical aspects of neutral, formal, and informal situations
- Superior (Mr Smith): "Would you give us a report on your department's work over the last three months, $\mathrm{Mr}$ Jones?"

- Subordinate (Mr Jones): "Yeah, sure."

The way Mr Jones replies to Mr Smith will probably make Mr Smith think that Mr Jones is behaving impolitely (effect). The following dialogue illustrates appropriate language use.

- Superior: "And now, could we go on to your report, Mr. Jenkins?"

- Subordinate/Mr Jenkins : "Certainly."

(Blundell, Higgens, \& Nigel, 1982, p. viii)

To be able to use the language appropriately, Blundell, Higgens and Nigel (1982) proposes a formula which can be seen in the following table.

\footnotetext{
*Author(s) Correspondence:

E-mail: nurdiana@bundamulia.ac.id
} 
This formula helps us to consider which language (neutral, formal, or informal language) should be used in certain situations. In other words, setting (where people are and when they use the language), topic (what people are talking about), social relationship (to whom people are talking), and psychological attitude (what people feel about a particular topic or people) determine what to say in the right time. As said earlier, Blundell, Higgens and Nigel (1982) proposed 135 language functions with more than 3,000 language expressions. Below are the examples of language functions and probable language expressions for each function.

\begin{tabular}{|c|c|c|}
\hline No. & Language functions & Possible language expressions \\
\hline 1. & Asking for information & $\begin{array}{l}\text { - } \quad \text { Can you tell me....? } \\
\text { - } \quad \text { Any clue....? } \\
\text { - } \quad \text { I hope you don't mind my asking, }\end{array}$ \\
\hline 2. & $\begin{array}{l}\text { Asking if someone knows about } \\
\text { something }\end{array}$ & $\begin{array}{ll}\text { - } & \text { Have you heard about....? } \\
\text { - } & \text { Know anything about....? } \\
\text { - } & \text { Can you give me any information about.....? }\end{array}$ \\
\hline 3. & Saying you know about something & $\begin{array}{l}\text { - } \quad \text { (Yes, I have heard about..... } \\
\text { - } \quad \text { So I've been told. } \\
\text { - } \quad \text { I am quite/fully aware of..... }\end{array}$ \\
\hline 4 & Saying you do not know & $\begin{array}{ll}\text { - } & \text { (I'm afraid) I don't know much about..... } \\
\text { - } & \text { I wish I knew... } \\
\text { - } & \text { I have to say I know very little about... }\end{array}$ \\
\hline 5 & Reminding & $\begin{array}{l}\text { - } \quad \text { I'd like to remind you about.... } \\
\text { - } \quad \text { I expect you've already done it, but.... } \\
\text { - } \quad \text { Don't forget about...... }\end{array}$ \\
\hline
\end{tabular}

Table 2. Examples of functions in English

Setting, topic, social relationship, and psychological attitude are pragmatically known as meta-pragmatic information. In relation to meta-pragmatic information, particularly to social relationship, Thomas (1999, as cited in Nurdiana, 2018, pp. 23-24) underlined the following points.

1. Power relationship

The higher the power you have, the more indirect you will speak to your interlocutors. For example, you prefer to use indirectness to someone whose position is higher than yours.

2. Social distance

The closer your relationship is with your interlocutors, the less indirect you will be to them. For instance, you will easily say "Can I borrow your money?" to your close friend.

3. Size of imposition

The greater the imposition is, the more direct you will be to your interlocutors. For example, you will be more direct if you ask for directions, but you will be less direct if you ask someone about their marital status.

4. Rights and obligations

You will be more direct when you ask for something which you think is your right. For example, when a teacher asks his/her students to do classroom activities, she/he will be more direct than when the teacher asks for help, e.g. asking his/her students to close the classroom door.

*Author(s) Correspondence:

E-mail: nurdiana@bundamulia.ac.id 
With regard to pragmatics, several studies on language functions have been carried out. One of them was conducted by Kohandani, Farzaneh, and Kazemi (2014). They investigated pragmatic informationlanguage functions and speech acts - in the conversations in 'Top Notch 1' textbook. The findings indicate that the conversations in the textbooks did not contain adequate amount of pragmatic information. In local English language course books, language functions are presented such as in the following materials.

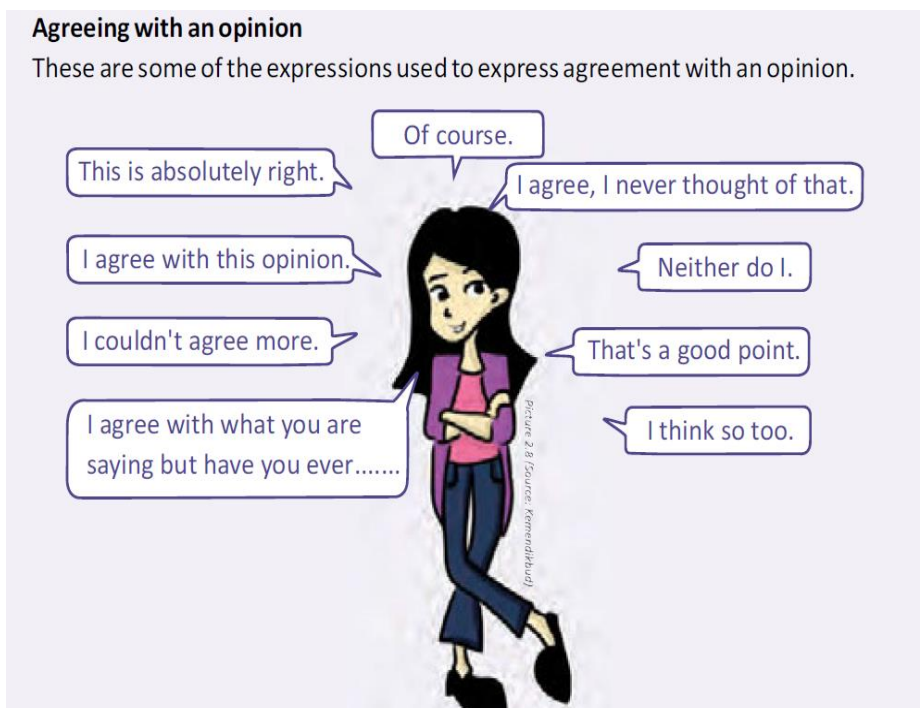

Source: Bashir (2017)

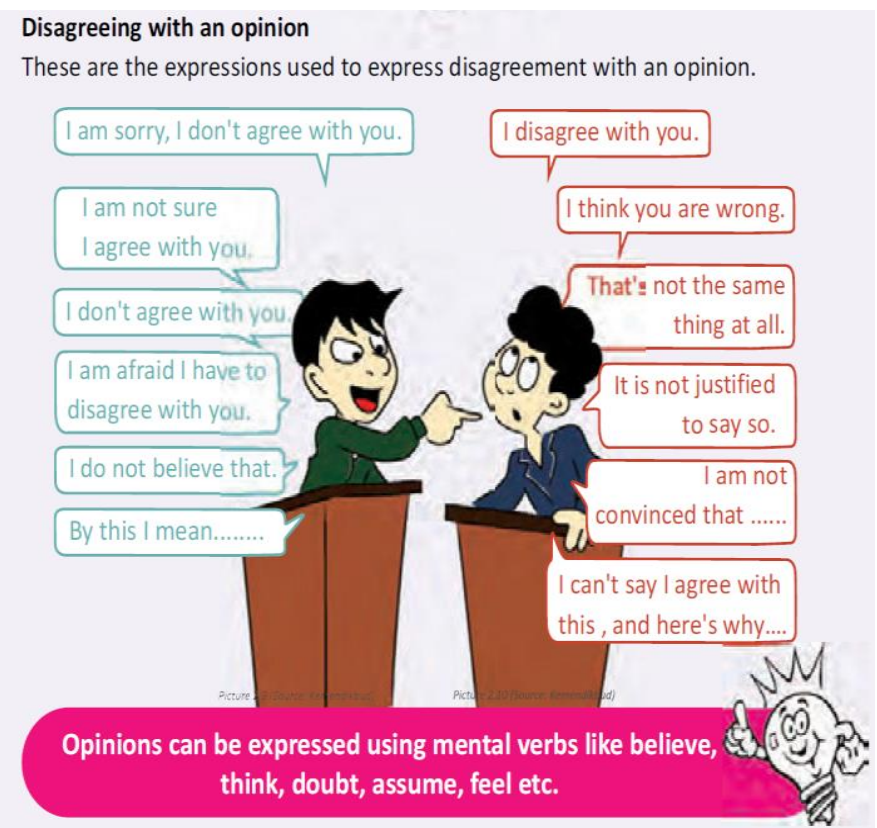

Source: Bashir (2017)

*Author(s) Correspondence:

E-mail: nurdiana@bundamulia.ac.id 


\begin{tabular}{|c|c|c|}
\hline Statement & Agree & Disagree \\
\hline $\begin{array}{l}\text { Smoking should be } \\
\text { banned in public } \\
\text { places. }\end{array}$ & $\begin{array}{l}\text { I totally agree that } \\
\text { smoking should be } \\
\text { banned in public places. }\end{array}$ & $\begin{array}{l}\text { I am sorry but I tend } \\
\text { to disagree with you } \\
\text { on this. }\end{array}$ \\
\hline $\begin{array}{l}\text { Children below } 16 \\
\text { should be given right } \\
\text { to drive a car. }\end{array}$ & $\begin{array}{l}\text { I couldn't agree more } \\
\text { with you. }\end{array}$ & $\begin{array}{l}\text { I think it would be } \\
\text { wrong to allow } \\
\text { children below age of } \\
16 \text { to drive. }\end{array}$ \\
\hline $\begin{array}{l}\text { Woman should not } \\
\text { work. }\end{array}$ & $\begin{array}{l}\text { I think so too. Women } \\
\text { should stay at home and } \\
\text { take care of their } \\
\text { children. }\end{array}$ & $\begin{array}{l}\text { I am afraid I have to } \\
\text { disagree with you on } \\
\text { this. }\end{array}$ \\
\hline $\begin{array}{l}\text { Harry Potter series is } \\
\text { much better than } \\
\text { Twilight series. }\end{array}$ & $\begin{array}{l}\text { Yes, I agree. Harry Potter } \\
\text { series has a much better } \\
\text { and well-developed } \\
\text { story line. }\end{array}$ & $\begin{array}{l}\text { It s not justified to say } \\
\text { because both have } \\
\text { different plots. }\end{array}$ \\
\hline $\begin{array}{l}\text { Online gaming should } \\
\text { be banned. }\end{array}$ & $\begin{array}{l}\text { Absolutely right, it } \\
\text { should be as it distracts } \\
\text { the students from } \\
\text { studying. }\end{array}$ & $\begin{array}{l}\text { I don't agree with you. } \\
\text { It is a venue for } \\
\text { students to develop } \\
\text { their skills. }\end{array}$ \\
\hline
\end{tabular}

Source: Bashir (2017)

The expressions above represent 'Agreeing and Disagreeing' and the examples of how language expressions of agreeing and disagreeing are used in context can be seen in the following dialogue.

\footnotetext{
Helmi : Retno, what do you think is the best action to reduce global warming?

Retno : I think everyone should start changing their way of life.

Helmi : What do you mean?

Retno : Well, we have to start to do what we can, to help reduce global warming.

Helmi : What do you suggest that we should do?

Retno : Well, there are lots of things that we can do. We should start saving electricity. start recycling things, start using public transport means, buying and consuming as much as we need only, etc. Basically. just save anything that we can.

Helmi : Wow! You know a lot of things about reducing global warming. Where did you learn all of that from?

Retno : Well, I read newspapers, magazines, and also search for information in the internet. Actually, I want to inform what I've learned to everyone so that everybody can start helping to save our mother nature.

Helmi : You're so awesome. How about if you write it in our school magazine next month?

Retno : That's a great idea. I'll do that.

Helmi : OK, l've got to go now.

Retno : Bye.
}

Source: Bashir (2017)

*Author(s) Correspondence:

E-mail: nurdiana@bundamulia.ac.id 


\section{Sociopragmatics}

Sociopragmatics constitutes pragmatic tools regarding social relationship among language users, social norms and rules in communities, and it deals with how people should pragmatically behave in terms of language use (Marmaridou, 2011). When people are knowledgeable of sociopragmatics, they might have a competence called sociopragmatic competence. According to Harlow (1990, p.328), sociopragmatic competence refers to the ability to "vary speech-act strategies according to the situational or social variables present in the act of communication." The competence deals with social rules of language use, language appropriateness, including social convention, and what language is considered taboo (Roever, 2009). Richards and Schmidt (2010) underline that sociopragmatics and sociopragmatic knowledge discuss the relationship between social factors and pragmatics. In other words, language users should take particular situations into account in order to be able to use appropriate language. To put it briefly, there are two indicators of sociopragmatics: formality/informality and appropriateness/inappropriateness.

When sociopragmatic competence fails to be achieved, the situation is called sociopragmatic failure. According to Thomas (1983), sociopragmatic failure is one type of pragmatic failure. Thomas (1983) further said that sociopragmatic failure is a term proposed by Leech (1983, as cited in Thomas, 1983) which refers to "social conditions placed on language in use."

\section{Pragmalinguistics}

This pragmatic aspect deals with the use of appropriate language form in certain circumstances (Richards and Schmidt, 2010). It is a linguistic form to make pragmatic function in target language knowledge (Roever, 2009). It consists of grammatical aspects such as the use of modal verbs and tenses (House \& Kasper, 1981; EconomidouKogetsidis \& Woodfield 2012; BardoviHarlig, 1999, as cited in Nurdiana, 2018). To make a request, for example, learners need to know the correct and the common linguistic forms of making a request (obscurity or common language forms). According to Kasper and Rose (2001, as cited in Nurdiana, 2018), pragmalinguistics is language forms used to make communication more polite." According to Richards and Schmidt (2010, p.449), pragmalinguistics is defined as:

"The interface between linguistics and pragmatics, focusing on the linguistic means used to accomplish pragmatic ends. For example, when a learner asks, "How do I make a compliment (or a request, or a warning) in this language?", this is a question of pragmalinguistics knowledge."This can be contrasted with sociopragmatics and sociopragmatic knowledge, which are concerned with the relationship between social factors and pragmatics. For example, a learner might need to know in what circumstances it is appropriate to make a compliment in the target language and which form would be most appropriate given the social relationship between the speaker and hearer."

When pragmalinguistic competence fails to be achieved, the situation is called pragmalinguitic failure. It implies that learners are not able to use common linguistic forms to serve particular functions when having a language interaction with their interlocutors.

\section{METHODOLOGY}

This paper is written on a secondary or library research basis. It implies that it is discussed based on or the sources of data which have been collected and analysed in relevant previous studies (Tavakoli, 2012). Therefore, the present paper is written with regard to some relevant research on pragmatics in language teaching, particularly on pragmatic competence in language teaching materials.

\footnotetext{
*Author(s) Correspondence:

E-mail: nurdiana@bundamulia.ac.id
} 
Previous studies employed in this paper are those conducted by Boxer \& Pickering (1995), Vallenga (2004), Nguyen (2011), Soozandehfar (2011), Kohandani, Farzaneh, \& Kazemi (2014), and Nurdiana (2018).

\section{FINDINGS AND DISCUSSION}

To understand the realization of four pragmatic aspects-language functions and meta-pragmatic information, sociopragmatics, and pragmalinguistics - in ELT materials, a pragmatic judgement task can be conducted by asking a native speaker of English to investigate the four pragmatic aspects. The following dialogue, taken from a local ELT course book, was examined by a native speaker of American English to study the relationship between language functions and meta-pragmatic information, sociopragmatics, and pragmalinguistics.

- Sri : "Hi, Asep. How are you?"

- Asep : "I'm fine. How about you?"

- Sri : "I'm fine too. Thank you."

- Asep : "Elvi, this is Denias, my new friend."
- Denias : "Hi. How do you do? Pleased to meet you."

- Sri : "How do you do? Pleased to meet you too."

Source: Doddy, Sugeng, \& Effendi (2008)

Through the conversation above, which represents language expressions of 'greetings', we can analyse sociopragmatics and pragmalinguistics. The sociopragmatic knowledge is seen from the formality and appropriateness while pragmalinguistic information is shown through the common expressions used in the conversation. According to a native speaker of American English, the expression 'How do you do' and 'pleased to meet you' in the dialogue above is too formal (sociopragmatics). They are not common for high school students in American English as these expressions are more commonly used by oldies or elderly (pragmalinguistics).

The following short conversation and the list of expressions represent 'making invitation'. They indicate the relationship between sociopragmatics and pragmalinguistics.

Robi invites Sandra to go to a movie.

Robi : Hi, Sandra. There will be a great film tonight. It's about Nasreddin. Would you like to go to the movie with me?

Sandra : Of course. I'd love to. When will you pick me up?

Robi : I'11 pick you up at 7.30. Be ready.

Sandra : OK.

*Author(s) Correspondence:

E-mail: nurdiana@bundamulia.ac.id 


\section{List of language expressions for 'making invitation'}

\begin{tabular}{|c|c|c|}
\hline \multicolumn{3}{|c|}{ Formal Situation } \\
\hline Inviting & Accepting an Invitation & Declining an Invitation \\
\hline $\begin{array}{l}\text { - Would you like to .... } \\
\text { - I'd very much like } \\
\text { you to .... } \\
\text { We should be } \\
\text { pleased/delighted if } \\
\text { you could .... } \\
\text { - Would you care to .... } \\
\text { - You will ... won't you? }\end{array}$ & $\begin{array}{l}\text { - That's very kind of you. } \\
\text { - We'd very much like } \\
\text { to .... } \\
\text { - What a delightful idea. } \\
\text { - With the greatest } \\
\text { pleasure. } \\
\text { - Thank you very much } \\
\text { for inviting me. }\end{array}$ & $\begin{array}{l}\text { - I'm very sorry, I don't } \\
\text { think I can. } \\
\text { - I'd like to, but .... } \\
\text { - } \quad \text { I'm afraid I've } \\
\text { already promised .... } \\
\text { - Thank you for asking } \\
\text { me, but .... } \\
\text { - Unfortunately, I can't } \\
\text {.... }\end{array}$ \\
\hline \multicolumn{3}{|c|}{ Informal Situation } \\
\hline Inviting & Accepting an Invitation & Declining an Invitation \\
\hline $\begin{array}{l}\text { - Why don't you come } \\
\text { to .... } \\
\text { - } \quad \text { Like to come to .... } \\
\text { - Come and .... } \\
\text { - Shall we come to .... } \\
\text { - You must come to .... }\end{array}$ & $\begin{array}{l}\text { - I would/will .... } \\
\text { - } \quad \text { That would be very nice. } \\
\text { - } \quad \text { OK! } \\
\text { - I'd like to love to come. } \\
\text { - }\end{array}$ & $\begin{array}{l}\text { - } \text { Sorry, I can't. } \\
\text { - I'd love to, but .... } \\
\text { - } \quad \text { I don't think I can. } \\
\text { - } \text { I wish I could, but .... }\end{array}$ \\
\hline
\end{tabular}

Source: Doddy, Sugeng, \& Effendi (2008)

The native speaker of American English said that 'I'd love to' and 'when will you pick me up?' in the conversation between 'Robi' and 'Sandra are not approriate and uncommon in this context because of their social relationship. Based on Blundell, Higgens and Nigel's (1982) formula of the use of language expressions, it can be inferred that the social relationship between the participants in the dialogue is informal (they are schoolmates); thus, the expressions used should be informal, too. 'Sandra' might have said 'OK' instead of 'of course, I'd love to'. The native speaker futher stated that in the conversation above, 'when will you pick me up?' is more commonly used by people who have a very close relationship.

The list of language expressions in the table also constitutes sociopragmatic and pragmalinguistic information. According to the native speaker, some of the expressions in the tables were inappproriately placed. In other words, those supposed to be classified as informal were considered as formal or vice versa. The examples of this are 'Would you like to....', 'Would you care to......', and 'You will.........won't you?' These expressions should have been placed in informal situation while in accepting an invitation, the expression 'I would/I will...' and 'That would be very nice.' are more appropriate in formal situation. The expressions in the list are even not the common ones in making invitation such as 'with the greatest pleasure' which is not common for accepting an invitation and ' $\mathrm{We}$ should be pleased/delighted if you could...'. which is a common expression for a written invitation. Another uncommon expression is 'What a delightful idea' which is normally used by elderly/oldies.

In Indonesian context, the interaction between high school students and native speakers or monolingual users of English is infrequent. However, the issue is not about how frequent the learners will use the language. The most significant thing is how they can have a good pragmatic competence in order to be able to avoid sociopragmatic and

*Author(s) Correspondence:

E-mail: nurdiana@bundamulia.ac.id 
pragmalinguistic failure in the actual communication. Learners needs a lot of exposure to authentic use of language expressions to serve pragmatic functions effectively. Consequently, they need to learn meta pragamatic information - when, where, and to whom it is appropriate to perform a particular language function and its expressions (Nguyen, 2011). Kasper and Bardovi-Harlig (1997, 2001, as cited in Salemi, Rabiee, \& Ketabi, 2012, p. 189) say that "appropriate and adequate input from teaching materials, especially ESL (English as a Second Language) textbooks, is crucial in the development of ESL learners' pragmatic competence." It is necessary for teachers to provide samples of conversations which are pragmatically effective or functional.

\section{CONCLUSION}

The findings and the discussion illustrate how to understand pragmatics, pragmatic competence, and how important they are in ELT materials and language teaching. As pragmatics is closely related to language use, to comprehend pragmatics in target language, teachers and learners should be knowledgable of at least the four aspects of pragmatics namely language functions and meta-pragmatic information, sociopragmatics, and pragmalinguistics. These four aspects may improve teachers' and learners' understanding to pragmatics so that they can use the language sociopragmatically and pragmalinguistically appropriate.

\section{REFERENCES}

Bashir, M. (2017). Bahasa Inggris. Pusat Kurikulum dan Perbukuan. Jakarta: Balitbang, Kemendikbud

Boxer, D. \& Pickering, L. (1995). Problems in the presentation of speech acts in ELT Materials. ELT Journal, 49(1), 44-58.
Blundell, J., Higgens, J., \& Nigel, M. (1982). Function in English. Oxford: Oxford University Press.

Crystal, D. (Ed.). (2003). Cambridge encylopedia of language. Cambridge: Cambridge University Press.

Doddy, A., Sugeng, A., \& Effendi. (2008). Developing English competencies for senior high school grade X. Jakarta: Pusat Perbukuan Departemen Pendidikan Nasional.

Harlow, L. L. (1990). Do they mean what they say? Sociopragmatic competence and second language learners. The Modern Language Journal, 74(iii), 328-50.

Harmer, J. (2007). How to teach English. Essex: Pearson Education Limited.

Kohandani, M., Farzaneh, N., \& Kazemi, M. (2014). A critical analysis of speech acts and language functions in Top Notch series. Procedia - Social and Behavioral Sciences, 98, 1009-1015.

Marmaridou, S. (2011). Pragmalinguistics and sociopragmatics. In W. Bublitz \& N.R. Norrick (Eds.). Foundations of pragmatics. Berlin/Boston: Walter de Gruyter GmbH \& Co. KG.

Nguyen, M.T.T. (2011). Learning to communicate in a globalized world: To what extent do school textbooks facilitate the development of intercultural pragmatic competence? RELC Journal, 42(1), 17-30.

Nurdiana. (2018). Language functions and speech acts in ELT materials: A case study of three Indonesian secondary school textbooks of English (Unpublished doctoral dissertation). Atma Jaya Catholic University of Indonesia, Jakarta, Indonesia.

Richards, J. C.\& Schmidt, R. (2010). Longman dictionary of language teaching and applied linguistics. London: Longman.

Roever, C. (2009). Teaching and testing pragmatics. In M. Long and C. J. Doughty (Eds.). The handbook of language teaching (pp. 560-577). Oxford: Blackwell.

Salemi, A., Rabiee, M., \& Ketabi, S. (2012). The effects of explicit/implicit

\footnotetext{
*Author(s) Correspondence:

E-mail: nurdiana@bundamulia.ac.id
} 
instruction and feedback on the development of Persian EFL learners' pragmatic competence in suggestion structures. Journal of Language Teaching and Research, 3(1), 188199.

Soozandehfar, S.M.A. (2011). A textbook evaluation of speech acts and language functions in Top-Notch Series. Theory and practice in language studies, 1(12), 1831-1838.

Tavakoli, H. (2012). A Dictionary of Research Methodology and Statistics in Applied Linguistics. Tehran: Rahnama Press

Thomas, J. (1983). Cross-cultural pragmatic failure. Applied Linguistics, 4(2), 91112.

Thomas, J. (1999). Pragmatics and English Language Teaching. In C. Ward \& W. A. Renandya (Eds.). New insights for the language teacher. Singapore: SEAMEO Regional Language Centre.
Vallenga, H. (2004). Learning pragmatics from ESL and EFL textbooks: How likely? TESL-EJ, 8(2). Retrieved June, 2015, from http://wwwwriting.berkeley.edu/TESLEJ/ej30/a3.h

Wichien, S. \& Aksornjarung, P. (2011). Pragmatic features in English course materials used at a Thai university. The $3^{\text {rd }}$ International Conference on Humanities and Social Sciences: Proceedings-English Studies in Various Contexts, 1-12

Yule, G. (1996). Pragmatics. Oxford: Oxford University Press.

*Author(s) Correspondence:

E-mail: nurdiana@bundamulia.ac.id 